\title{
Rainfall and Temperature Distinguish Between Karnal Bunt Positive and Negative Years in Wheat Fields in Texas
}

\author{
F. Workneh, T. W. Allen, G. H. Nash, B. Narasimhan, R. Srinivasan, and C. M. Rush
}

First, second, and sixth authors: Texas Agricultural Experiment Station, Bushland 79012; third author: USDA-APHIS-PPQ, Austin 78701; fourth and fifth authors, Spatial Science Laboratory, Texas A\&M University, College Station 77843. Accepted for publication 15 July 2007.

\begin{abstract}
Workneh, F., Allen, T. W., Nash, G. H., Narasimhan, B., Srinivasan, R., and Rush, C. M. 2008. Rainfall and temperature distinguish between Karnal bunt positive and negative years in wheat fields in Texas. Phytopathology 98:95-100.

Karnal bunt of wheat, caused by the fungus Tilletia indica, is an internationally regulated disease. Since its first detection in central Texas in 1997, regions in which the disease was detected have been under strict federal quarantine regulations resulting in significant economic losses. A study was conducted to determine the effect of weather factors on incidence of the disease since its first detection in Texas. Weather variables (temperature and rainfall amount and frequency) were collected and used as predictors in discriminant analysis for classifying buntpositive and -negative fields using incidence data for 1997 and 2000 to 2003 in San Saba County. Rainfall amount and frequency were obtained from radar (Doppler radar) measurements. The three weather variables correctly classified $100 \%$ of the cases into bunt-positive or -negative fields during the specific period overlapping the stage of wheat sus-
\end{abstract}

ABSTRACT ceptibility (boot to soft dough) in the region. A linear discriminantfunction model then was developed for use in classification of new weather variables into the bunt occurrence groups (+ or - ). The model was evaluated using weather data for 2004 to 2006 for San Saba area (central Texas), and data for 2001 and 2002 for Olney area (north-central Texas). The model correctly predicted bunt occurrence in all cases except for the year 2004. The model was also evaluated for site-specific prediction of the disease using radar rainfall data and in most cases provided similar results as the regional level evaluation. The humid thermal index (HTI) model (widely used for assessing risk of Karnal bunt) agreed with our model in all cases in the regional level evaluation, including the year 2004 for the San Saba area, except for the Olney area where it incorrectly predicted weather conditions in 2001 as unfavorable. The current model has a potential to be used in a spray advisory program in regulated wheat fields.

Additional keywords: canonical discriminant analysis, Karnal bunt forecast, smut.
Karnal bunt of wheat caused by Tilletia indica Mitra was first described in India in 1931 (27). Since then the disease has been reported to occur in several other countries including Mexico $(8,12,16)$. In the United States, Karnal bunt was observed for the first time on durum wheat in Arizona in 1996 (51) and soon was detected in the adjacent Imperial Valley of California (21). In Texas the disease was discovered in 1997 in San Saba County (central Texas), where several fields tested positive. Monitoring of wheat fields in the county during the subsequent 3 years revealed no additional occurrence of the disease until 2001, when bunted kernels were detected in grain samples from 66 fields including one field in adjacent McCulloch County. The same year bunted kernels were found in 27 fields in four additional counties of the Rolling Plains (Archer, Baylor, Throckmorton, and Young) of north-central Texas, approximately $200 \mathrm{~km}$ north of San Saba County. In 2002, grain samples from four additional fields tested positive for the disease in three of these counties (Baylor, Throckmorton, and Young) (31).

Karnal bunt of wheat is generally considered a minor disease with regard to its impact on yield $(3,6,25,31)$. The causal organism, $T$. indica, like most any other smut fungi, has to form a dikaryotic mycelium for successful infection and subsequent onset of teliosporogenesis (48). However, as a heterothallic fun-

Corresponding author: F. Workneh; E-mail address: f-workneh@tamu.edu

doi:10.1094/PHYTO-98-1-0095

This article is in the public domain and not copyrightable. It may be freely reprinted with customary crediting of the source. The American Phytopathological Society, 2008. gus, it requires a conjugation of two compatible mating types for occurrence of plasmogamy (17). Therefore, in low populations of the pathogen the probability of successful infection is low even under favorable environmental conditions because of what is known as the Allee effect (19). In addition, wheat is vulnerable only during a 2- to 3-week window of its physiological development, and environmental conditions have to be conducive during this short period for successful infection. The low probability of infection is evident from the fact that, since its first detection in 1996, the vast majority of positive durum wheat fields in Arizona had infection levels of less than $0.02 \%$ (31).

However, the significance of Karnal bunt surfaces in its effect on grain quality. Bunted grains impart a fishy odor to the flower, rendering the bread unpalatable if infection level is greater than $3 \%$ of the kernels $(25,45)$. For this reason, regions with positive Karnal bunt are subject to strict international regulations $(8,31)$. In Texas, fields which tested positive were placed under strict, zero tolerance, federal quarantine immediately after detection. Wheat fields within a 3-mile radius of infected fields also were placed under regulation. These measures cost growers over \$25 million in four of the counties in 2001 and 2002, primarily due to loss of export markets (31).

Kernels infected with $T$. indica are generally partially bunted, and as in any other family of smut fungi, the pathogen produces characteristic dark-colored sori (mass of teliospores [10]) in the kernels, which are disseminated by air currents and deposited into the soil during harvest or during any mechanical operations. Teliospores are reported to survive in the soil at least for 4 years under field conditions (7) and presumably longer in the laboratory (26). Teliospores near the soil surface germinate and produce multiple 
sporidia (primary sporidia), which are splashed by rain or blown onto the wheat crop by air currents $(29,33,45)$. Primary sporidia give rise to secondary sporidia by budding, which continuously multiply on leaf surfaces and infect during the vulnerable stage of wheat development $(4,13)$. The susceptible period is generally regarded to be between the boot stage and soft dough stage, approximately a 2- to 3-week period, depending on the cultivar and the weather conditions (37). The boot stage is considered susceptible based on artificial injection with $T$. indica inoculum $(9,11,30,46)$. However, a recent finding by Goates and Jackson (20), that spikes can only be infected after emergence, casts doubt on whether natural infection actually occurs at the boot stage.

Efforts are underway to incorporate resistance genes into commercial cultivars, but at present there are no resistant cultivars available in the United Sates (31). The only viable management options are seed treatments, to eradicate teliospores in or on the seeds, and foliar fungicide sprays $(38,47)$. Some systemic (curative) and protective fungicides have been shown to be very effective when applied onto exposed spikes $(24,34,38)$. In light of the present quarantine situation surrounding Karnal bunt, and its economic consequences, spray application for control of the disease would be a viable option. However, Karnal bunt is a weatherdriven disease and conditions favorable for disease development do not exist every year. Therefore, spraying for the disease every year would be an unnecessary waste of time and resources. A weather-based Karnal bunt forecasting model, which can predict the conduciveness of the weather conditions during the window of wheat vulnerability, would be useful in making management decisions if incorporated into a spray advisory program.

Karnal bunt is generally a cool weather disease and weather conditions during the susceptible period are critical factors in bunt development. A temperature range of 18 to $22^{\circ} \mathrm{C}$, coupled with high relative humidity, is considered optimum for infection (2, 33). However, rainfall episodes during the susceptible period appear to be playing a predominant role in disease development $(14,25,35,36)$. In nonirrigated fields, rainfall provides moisture for the dry conditions near the soil surface thereby enabling teliospores to germinate. Rainfall is also important for splash dispersal of both primary and secondary sporidia, and for eventual infection of wheat spikes by creating humid conditions (45). However, rainfall distribution is highly variable both in quantity and frequency, even within a small area, and existing ground weather stations are too far apart to account for the variability. Thus, use of ground weather stations for measurement of rainfall to represent a given region may lead to erroneous conclusions. Radarbased rainfall measurements, however, have a resolution of $4 \times$ $4 \mathrm{~km}$ (18) and have been used in the past for modeling regional disease prevalence $(49,50)$. In this study we will explore the suitability of radar rainfall data for general and site-specific prediction of Karnal bunt.

Currently, there are weather-based Karnal bunt risk assessment models $(23,24,35,39)$, one of which is known as the humid thermal index (HTI) developed by Jhorar et al. $(23,24)$. This particular model is widely used by researchers in assessing the risk of establishment of Karnal bunt in new territories $(5,28,40,41)$. The index is based on afternoon relative humidity (referred to as evening relative humidity) and maximum temperature-the average of the ratio of relative humidity at 2:30 p.m. and maximum temperature during the window of host susceptibility (23). A major limitation in trying to use this model is that measurements of hourly or half-hourly relative humidity are not readily available, especially in rural areas. Relative humidity is greatly affected by isolated rain showers and is highly variable from locale to locale. Use of relative humidity data from distant weather stations may lead to erroneous conclusions.

The primary objectives of this project were to (i) determine weather factors associated with Karnal bunt occurrence in Texas during the last 10 years and develop a weather-based forecasting model, and (ii) determine whether the HTI model describes Karnal bunt occurrence in Texas.

\section{MATERIALS AND METHODS}

Grain sampling and bunted kernel assessment. Each year during the last 10 years (1997 to 2006), representative grain samples from regulated fields were harvested with a combine harvester by arbitrarily driving the harvester through the fields until it was full. As the harvester discharged the grain onto a truck, a 1.8-kg subsample (approximately 65,000 kernels per field) was intermittently collected using a PVC pipe. Initially, bunted kernels were assessed by visually examining each kernel but a high-speed optical sorter (ScanMaster II, Satake USA Inc., Stafford, TX) was later introduced to speed up the process of separation of bunted kernels (15). Kernels suspected to be infected were examined under a microscope to confirm the presence of teliospores. Slides of known teliospores of $T$. indica were used as a reference guide to verify that observed teliospores were those of T. indica. Because of the zero tolerance quarantine, the occurrence of bunted kernels in grain samples from each field was recorded as present or absent (+ or - ). An average of 150 fields were sampled each year and tested for Karnal bunt as described above.

Weather data collection. Temperature data for the San Saba area were obtained from the National Weather Service station (NWS) in San Saba and Brady (in adjacent county of McCulloch). For fields in Olney area in north-central Texas, temperature data were obtained from one or two available NWS stations in each of the four contiguous counties (Archer, Baylor, Throckmorton, and Young) where Karnal bunt was observed. Radar rainfall data for the field locations for both San Saba and Olney area were downloaded from the Texas Weather Connection (TWC) site (Spatial Science Laboratory, Texas A\&M University) by providing the GPS coordinates of each field.

Data analysis. Many of the fields which tested positive in 1997 and 2001 in San Saba County, were removed out of wheat production due to federal restrictions. Therefore, only fields which had recorded histories of Karnal bunt, and were planted to wheat, and tested for Karnal bunt in any given year between 1997 and 2006, were included in the analysis. Maximum temperature and precipitation amount and frequency (percent of days in which rainfall occurred) were used in discriminant function analysis to classify wheat fields into bunt-positive and -negative fields in San Saba County using SAS software version 9.1 (SAS Institute Inc., Cary, NC). Averages of each of the three weather variables for various intervals ranging between 15 and 30 days in April were tested for their ability to distinguish between the two Karnal bunt occurrence groups (present or absent).

Discriminant function analysis is a multivariate technique which classifies cases into one of two or more classes on the basis of one or more variables $(1,43,44)$. The analysis is subject to assumptions of multivariate normality and equality of variances among the groups under consideration. The analysis is generally robust to failures of normality if the sample size is large enough relative to the number of subjects (44). However, it is highly sensitive to heterogeneity of variances, especially if the primary goal of the analysis is classification, because cases tend to classify into the group with greater dispersion $(1,44)$. The remedy for failures of the assumptions is to use either a nonparametric method, which makes no assumptions of distribution, or use the within covariance matrices instead of pooling. However, if there is a near perfect separation of the groups, use of any of the methods would not significantly affect the outcome regardless of the violation of the assumptions (44). In this study there was a clear-cut separation between fields with and without Karnal bunt and, thus, use of any of the three methods did not change the outcome. Therefore, the covariance matrices were pooled to obtain a classification function for each bunt occurrence group from which a 
linear discriminant function coefficients and a dividing or cutting point, also known as a constant (C), for classification of new cases (prediction) were computed $(1,43)$.

In the discriminant analysis, prior probability of membership was set proportional to the number of fields in each bunt occurrence group. An unbiased estimate of the correct classification was produced by cross validation, also known as the jackknife procedure (44), which involves exclusion of each observation from the analysis and reclassification of the excluded observation. Canonical discriminant analysis was run to determine the relative strengths of the variables, and to obtain a graphical representation of the classification along the canonical axes.

Model evaluation. Five years of data (1997 and 2000 to 2003) were used in development of a model for fields in San Saba County. As indicated earlier, this was primarily dictated by prior bunt history of fields and whether the fields were planted to wheat or not. The data for 2004 to 2006 from fields in San Saba County, and 2001 and 2002 from fields in Olney area in the north then were used to evaluate the model. Evaluations were conducted at two levels. The first was a regional level evaluation, in which averages of weather variables representing the region were used. In this procedure the HTI model (23) also was evaluated along with the current model. Temperature and relative humidity data for the HTI model were obtained from stations approximately 30 to $40 \mathrm{~km}$ outside of the borders of the counties in which Karnal bunt was detected. The second evaluation consisted of the use of radar rainfall data along with temperature data from a weather station closest to each field for site-specific forecast of the occurrence of Karnal bunt at individual field level.

The new observations were classified into either group depending on whether their discriminant scores $(Z)$ were greater or lower than $C$. The weather observations were inserted into the linear discriminant function, $Z=b_{1} X_{1}-b_{2} X_{2}-b_{3} X_{3}$, where $X_{1}, X_{2}$, and $X_{3}$ are maximum temperature $\left({ }^{\circ} \mathrm{C}\right)$, rainfall amount (mm), and frequency, respectively, and $b_{1}, b_{2}$, and $b_{3}$ are their respective coefficients. Scores greater than the dividing point were classified as unfavorable, and vice versa. The probability of belonging to group 0 (Karnal bunt absent) then was computed as $1 / 1+\exp (-Z+C)$, where $Z$ and $C$ are as described. The probability of belonging to group 1 (Karnal bunt present) was obtained by subtraction.

\section{RESULTS}

There were a total of 53 fields which had histories of Karnal bunt occurrence, either in 1997 or in 2001 (or both), and were planted to wheat at least once after the detection of the disease. All fields planted to wheat in 1998 and 1999 had no record of Karnal bunt occurrence in 1997. In addition, Karnal bunt was not detected in any field in Texas in 1998 and 1999, and the presence of the pathogen in the soil was uncertain. Thus, data for these 2 years were not included in the analysis. Karnal bunt was not detected in any of the 53 fields in 2000, 2002, or 2003 even though these fields had prior history of the disease and teliospores of the pathogen were recovered from soils sampled from about $93 \%$ of these fields (42). Overall, there were 30 fields in which Karnal bunt was detected and 23 fields in which it was not detected.

Discriminant analysis of the bunt occurrence data distinctly separated the 53 fields into bunt-positive and -negative fields based on the weather factors. The three predictor variables, average maximum temperature, rainfall amount, and rainfall frequency, for an 18-day period (April 8 to 25), best separated fields with Karnal bunt from those without Karnal bunt in San Saba County (Fig. 1). During the 18-day period, there were distinct differences in weather conditions between years with (1997 and 2001) and without (2000, 2002, and 2003) Karnal bunt. Years in which Karnal bunt was detected were cooler and wetter than those in which Karnal bunt was not detected (Table 1). Average rainfall amount for the years with Karnal bunt was about eight times greater than for those without Karnal bunt, and the average rainfall frequency was greater by approximately $28 \%$.

The three variables correctly classified all $(100 \%)$ cases into either group (posterior probability error rate estimates of zero) producing a complete separation of the two groups, in which the first canonical function accounted for $100 \%$ of the variation with average squared canonical correlation of 0.92 . Rainfall amount had the strongest effect in distinguishing the two groups, with the standardized coefficient of -0.87 , followed by maximum temperature $(0.77)$ and rainfall frequency $(-0.67)$. A Karnal bunt occurrence model, $Z=6.6 X_{1}-9.45 X_{2}-1.12 X_{3}$, then was developed using the linear combinations of the discriminant function coefficients in which $X_{1}$ is average maximum temperature, $X_{2}$ is average

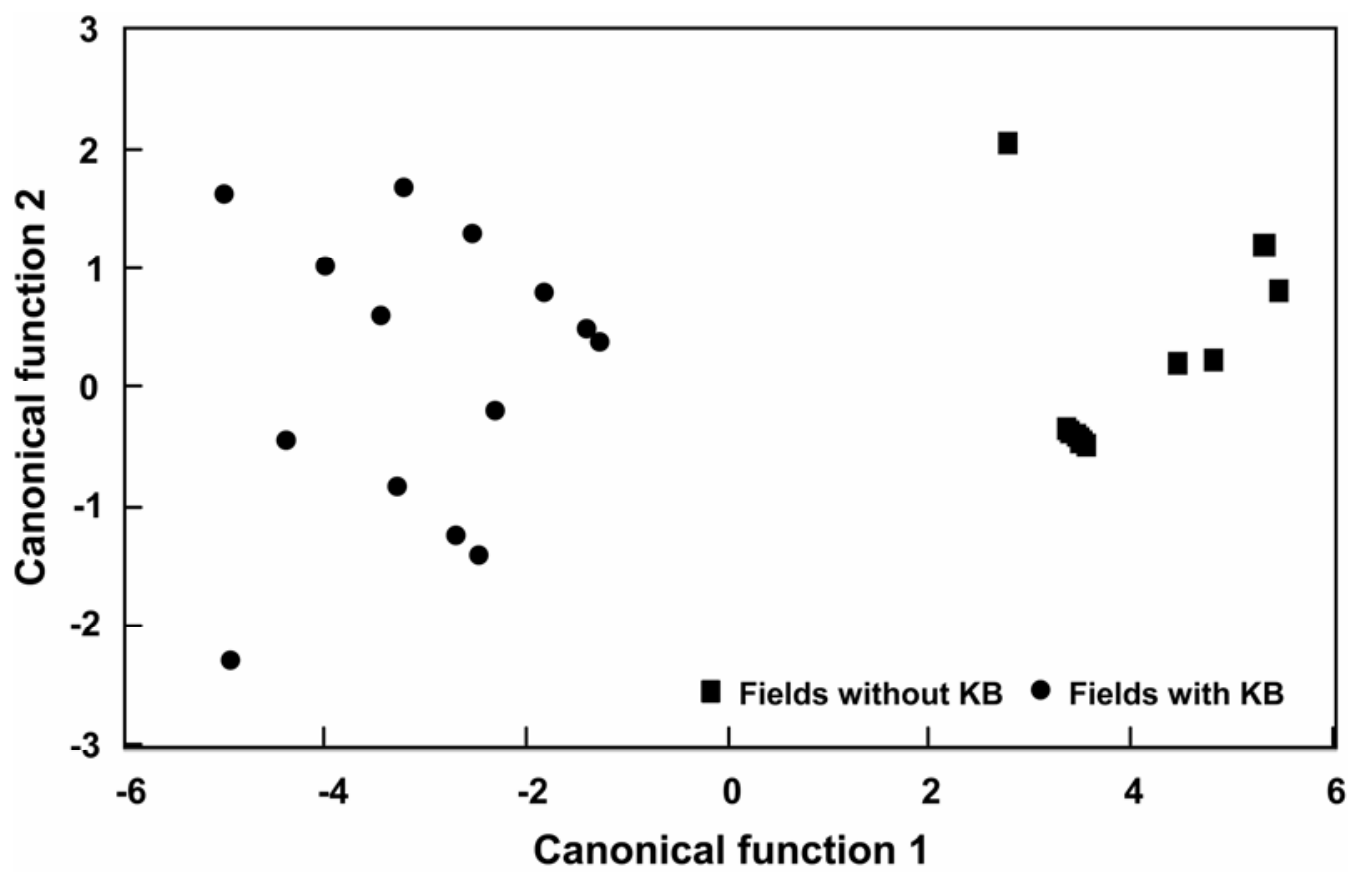

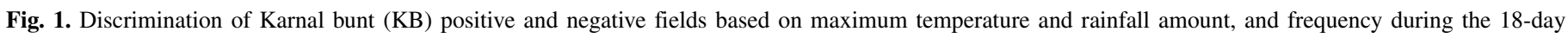
period (April 8 to 25) in 1997 and 2000 to 2003 in Texas, using the first and second canonical functions. 
rainfall amount, and $X_{3}$ is average rainfall frequency for the 18-day period (Table 2). The discriminant function coefficients were obtained by subtracting the classification function coefficients of the variables of fields with Karnal bunt from their respective variables of fields without Karnal bunt. The dividing point $(C=135.95)$ for classifying new observations was computed similarly from the constants but in reverse order (1).

Evaluation of the model by inserting new weather observations (not used in model development) for San Saba County showed that the year 2004 was highly favorable for bunt development even though Karnal bunt was not detected that year in any of the fields in the county. The discriminant score $(Z)$ for the year was lower than the dividing point, with a $100 \%$ probability of being a Karnal bunt-favorable year (Table 3). However, the $Z$ scores for 2005 and 2006 were higher than the cutting point with 98 and $100 \%$ probability, respectively, indicating that the 2 years were unfavorable for the disease, agreeing with the absence of Karnal bunt during the 2-year period.

The $Z$ scores for the Olney area were lower than the cutting point, indicating that weather conditions in Olney area were favorable for bunt development in both 2001 and 2002, with the probability of 97 and $100 \%$, respectively. The model described April 8 to 25 in 2001 and April 5 to 20 in 2002 as the most

TABLE 1. Mean maximum temperature, rainfall amount and frequency (\%), and their standard deviations for an 18-day period (April 8 to 25) for fields in which Karnal bunt was detected or not detected during the 5-year period (1997 and 2000 to 2003) in the San Saba area in Texas

\begin{tabular}{llrc}
\hline Karnal bunt & \multicolumn{1}{c}{ Variable } & Mean & $\begin{array}{c}\text { Standard } \\
\text { deviation }\end{array}$ \\
\hline Negative $(n=23)$ & Maximum temperature $\left({ }^{\circ} \mathrm{C}\right)$ & 27.17 & 1.01 \\
& Rainfall amount $(\mathrm{mm})$ & 0.29 & 0.35 \\
\multirow{2}{*}{ Positive $(n=30)$} & 16.18 & 3.31 \\
& Rainfall frequency ${ }^{\mathrm{a}}$ & 24.22 & 0.56 \\
& Maximum temperature $\left({ }^{\circ} \mathrm{C}\right)$ & 2.34 & 0.77 \\
& Rainfall amount $(\mathrm{mm})$ & 22.41 & 4.49 \\
\hline
\end{tabular}

a Percentage of days in which there were rainfall events during the 18-day period.

TABLE 2. Classification function and discriminant function coefficients of fields with and without Karnal bunt based on maximum temperature and rainfall amount and frequency in Texas

\begin{tabular}{lccc}
\hline & \multicolumn{3}{c}{ Classification function } \\
\cline { 2 - 4 } Variable & $\begin{array}{c}\text { Karnal bunt } \\
\text { negative }(n=23)\end{array}$ & $\begin{array}{c}\text { Karnal bunt } \\
\text { positive }(n=30)\end{array}$ & $\begin{array}{c}\text { Discriminant } \\
\text { function }\end{array}$ \\
\hline Maximum temperature & 45.33 & 38.73 & 6.60 \\
Rainfall amount & -9.84 & -0.39 & 9.45 \\
Rainfall frequency & -0.69 & 0.43 & -1.12 \\
Constant & -609.89 & -473.94 & 135.95 \\
\hline
\end{tabular}

favorable periods for bunt development. Overall, except for the year 2004 (San Saba), the model correctly predicted Karnal bunt occurrence at both locations (Table 3 ).

The HTI model developed by Jhorar et al. (23) produced similar results as the current model in San Saba County including for the year 2004. For the HTI model, weather conditions are favorable for Karnal bunt development when the index is within the range of 2.2 to 3.3 but unfavorable outside the range. For the Olney area the index value of 1.83 indicated that weather conditions were unfavorable for Karnal bunt occurrence in 2001, despite detection of Karnal bunt in wheat fields that year. However, the index correctly predicted 2002 as a bunt favorable year.

Site-specific evaluation of the model for San Saba County produced more or less similar results as the regional level evaluation (Table 4). With 2004 data, all fields were incorrectly predicted by the model as Karnal bunt positive when in fact no Karnal bunt was detected in any of the 13 fields tested. However, the model correctly predicted 17 of the 19 fields $(89.5 \%)$ as Karnal bunt negative in 2005 and in all of the 5 fields in 2006. In 2001, 27 fields tested Karnal bunt positive in Olney area. The model correctly predicted 17 of them as bunt-positive fields (63\%). However, only four fields tested positive in 2002, and the model correctly predicted all of them as bunt-positive.

\section{DISCUSSION}

Even though Karnal bunt is considered a minor disease in its impact on grain yield, it has gained considerable attention since its first official detection in the United States in 1996. This was largely because of the associated quarantine regulations which led to significant economic losses. In Texas, the disease has not been continually observed since it was discovered in 1997. In this study we investigated the effect of weather factors on its occurrence during the last 10 years, with the ultimate goal that the finding might lead to forecasting of the disease. Discriminant analysis was useful in distinguishing between bunt-positive and -negative

TABLE 4. Evaluation of the Karnal bunt model for site-specific prediction (close to field level) in San Saba and Olney area in Texas from 2004 to 2006 and 2001 and 2002, respectively

\begin{tabular}{lcccc}
\hline Location & Year & $\begin{array}{c}\text { No. of } \\
\text { fields }\end{array}$ & $\begin{array}{c}\text { Karnal bunt status } \\
\text { of fields }\end{array}$ & $\begin{array}{c}\text { Correct } \\
\text { prediction }(\%)^{\mathrm{a}}\end{array}$ \\
\hline San Saba & 2004 & 13 & Negative & 0.00 \\
& 2005 & 19 & Negative & 89.47 \\
& 2006 & 5 & Negative & 100.00 \\
Olney area & 2001 & 27 & Positive & 63.00 \\
& 2002 & 4 & Positive & 100.00 \\
\hline
\end{tabular}

a The numbers represent the percentage of fields that the model correctly predicted as having or not having Karnal bunt during the corresponding year.

TABLE 3. Evaluation of the Karnal bunt model using regional weather variables (maximum temperature, rainfall amount, and rainfall frequency) for fields in San Saba in 2004, 2005, and 2006 and for fields in Olney in 2001 and 2002 in Texas

\begin{tabular}{|c|c|c|c|c|c|c|c|c|c|c|}
\hline \multirow[b]{2}{*}{ Location } & \multirow[b]{2}{*}{ Year } & \multirow[b]{2}{*}{$\begin{array}{l}\text { No. of } \\
\text { fields }\end{array}$} & \multirow[b]{2}{*}{$\begin{array}{c}\text { Karnal bunt } \\
\text { status }\end{array}$} & \multirow{2}{*}{$\begin{array}{l}\operatorname{Max} \\
\text { temp. } \\
\left({ }^{\circ} \mathrm{C}\right)^{\mathrm{a}}\end{array}$} & \multirow{2}{*}{$\begin{array}{c}\mathrm{PRCP}^{\mathrm{b}} \\
\text { amount } \\
(\mathrm{mm})\end{array}$} & \multirow{2}{*}{$\begin{array}{c}\mathrm{PRCP}^{\mathrm{c}} \\
\text { frequency } \\
(\%)\end{array}$} & \multirow[b]{2}{*}{$Z^{\mathrm{d}}$} & \multicolumn{2}{|c|}{ Probability of membership ${ }^{\mathrm{e}}$} & \multirow[b]{2}{*}{$\mathrm{HTI}^{\mathrm{f}}$} \\
\hline & & & & & & & & $\begin{array}{c}\text { Karnal bunt } \\
\text { negative }\end{array}$ & $\begin{array}{c}\text { Karnal bunt } \\
\text { positive }\end{array}$ & \\
\hline \multirow[t]{3}{*}{ San Saba } & 2004 & 13 & Negative & 22.45 & 3.27 & 41.18 & 71.15 & 0.00 & 1.00 & 2.66 \\
\hline & 2005 & 19 & Negative & 25.01 & 0.38 & 19.30 & 139.86 & 0.98 & 0.02 & 1.72 \\
\hline & 2006 & 5 & Negative & 30.60 & 0.70 & 6.67 & 187.87 & 1.00 & 0.00 & 1.31 \\
\hline \multirow[t]{2}{*}{ Olney } & 2001 & 27 & Positive & 24.49 & 1.05 & 17.39 & 132.23 & 0.03 & 0.97 & 1.92 \\
\hline & 2002 & 4 & Positive & 25.02 & 4.89 & 33.27 & 81.66 & 0.00 & 1.00 & 2.30 \\
\hline
\end{tabular}

a Max. temp. represents average maximum temperature.

b PRCP amount represents average precipitation amount.

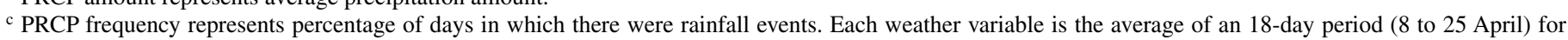
San Saba (2004 to 2006) and Olney (2001), and a 16-day period (5 to 20 April) for Olney (2002).

d $Z$ is a discriminant score. Scores less than the cutting point (135.95) predict the existence of favorable conditions for bunt development, and vice versa.

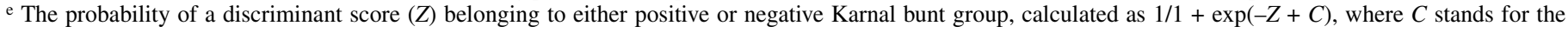
cutting point.

${ }^{\mathrm{f}}$ HTI stands for humid thermal index and values between 2.3 and 3.3 suggest the existence of favorable conditions. 
fields based on the weather variables. An equally useful analysis method would have been the use of logistic regression. However, in this study, logistic regression could not be used because maximum likelihood could not be estimated due to the complete separation of the two bunt occurrence groups (22).

It may appear that a $1.8 \mathrm{~kg}$ subsample would not be adequate to represent a field. However, considering the fact individual kernels had to be scrutinized (approximately 65,000 kernels and 2,166 to 3,250 plants per field), greater sample size would have required more time and resources, and as in any sampling procedures, there had to be a balance between manageable sample size and precision. In reality, our sample was the number of kernels, since the detection of one kernel in the sample would render the field positive. In addition, it is evident from the result that the sample size we used clearly distinguished between bunt-positive and -negative fields.

The study revealed that rainfall and temperature were major factors affecting Karnal bunt occurrence in Texas. Consequently, a weather-based model for forecasting the risk of the disease was developed. The model was evaluated using weather data from both bunt-negative and -positive fields not used in model development. In all cases, the model correctly predicted the occurrence of the disease except for the year 2004 where weather conditions were predicted as favorable although no disease was detected that year. The fact that the model predicted 2004 as a bunt-favorable year was not surprising, because based on data presented in the literature relating to weather factors, there should have been a Karnal bunt incidence. The weather was cool and wet during the susceptible stage of wheat development, with rainfall occurring at least seven times during the 18-day period (41.2\%) in April 2004. This rainfall frequency was far greater than other bunt conducive periods since the discovery of the disease. The amount of rainfall also was almost twice as much as in any of the other years. It is interesting that the HTI model also predicted 2004 as a bunt-favorable year.

It is possible that 2004 was too wet for development of Karnal bunt. This view is supported by observations made in India that prolonged wet conditions are unfavorable for Karnal bunt development (32). Jhorar et al. (23) also reported that conditions for development of Karnal bunt are unfavorable when HTI values are too high. Large HTI values are the results from high relative humidity and cool temperatures. However, in this case the HTI value was within the favorable range (2.66) and, thus, it cannot be concluded that 2004 was unfavorable based on the value of the index. However, as indicated earlier, the weather station used for evaluation of the HTI model was too far from the study fields and thus the values presented in this paper may not necessarily reflect actual conditions in the field.

It is unclear why prolonged wet conditions can be unfavorable for Karnal bunt development. One possible explanation is that excessive rainfall may wash off the sporidia from plants thereby reducing infection. Also as pointed out for the Indian situation, excessive rainfall may have created conducive conditions for spore germination before the onset of the susceptible stage of the host, exhausting the inoculum (32). In addition, even though the model predicted highly favorable conditions, the possibility that the disease might have been below detection level cannot be ruled out. Further investigations are necessary to determine the effect of wetness durations on Karnal bunt occurrence. One may argue that in 2002, the rainfall amount in Olney area was greater than that in San Saba in 2004. However, the rainfall frequency was lower and the temperature was higher in Olney area than in San Saba, and only four fields tested positive as opposed to 27 in 2001.

The weather variables clearly distinguished between bunt-positive and -negative fields during the 18-day period in April, which overlapped the physiological stage of wheat development at which the crop is susceptible to infection by $T$. indica. Certainly the 18day period is not a fixed period because infection can occur within a few days, and the period may vary from year to year, both in duration and time of onset depending on weather conditions.
However, the susceptible window (boot to soft dough stage) is generally estimated to range from the first- to the last week of April in San Saba and may run until the end of April in Olney in the north. The fact that the model developed for San Saba area accurately described the disease conditions in the north, with little variation in time durations, indicates the existence of extensive overlap in the stage of susceptibility between the two regions.

The current Karnal bunt model predicts conduciveness of the weather conditions but does not predict disease severity because of the nature of the data collected. Due to the zero-tolerance regulations, bunted kernel occurrence was recorded as present or absent regardless of the number of bunted kernels observed. However, one can insert new weather variables (or average values for a given period) in the model to determine whether the conditions are favorable for occurrence of the disease. If the discriminant score $(Z)$ is greater than the dividing point (135.95), then it is unlikely that environmental conditions are favorable. The probability that conditions are favorable or unfavorable can be calculated using the probability algorithm described earlier. The probability values range from 0 to 1 and if the value is 1 or close to 1 , then it is highly probable that conditions are not favorable during the specified period. The algorithm gives the probability of unfavorable conditions but the probability of favorable conditions can be determined by subtraction ( 1 - probability of unfavorable conditions).

The importance of rainfall in development of Karnal bunt and other bunt diseases has been documented $(25,35,36)$. Two of the three variables used in this study were rainfall variables (amount and frequency), which had major effects in distinguishing between bunt-positive and -negative fields. In this study spatial variability of rainfall was largely accounted for using Doppler radar, which has a $4 \times 4 \mathrm{~km}$ resolution. The resolution of the estimates is far closer to the field-level rainfall estimates than those from ground-based weather stations, which are generally in the order of one station per county. The radar rainfall estimates were useful in evaluating the model site-specifically (close to field level) even though there may have been more than one field within each of the $4 \times 4 \mathrm{~km}$ area sharing the same rainfall estimate.

As expected, there were variations in rainfall frequency and amount among fields, leading to different outcomes in the sitespecific evaluation of the model. For example, results of the sitespecific evaluation entirely agreed with that of the regional level for 2004, and 2006 for San Saba, and 2002 for Olney area. However, for 2005 in San Saba, even though disease was correctly predicted not to occur in the regional level evaluation, the site-specific evaluation predicted that disease would occur in 2 of the 19 fields. Also in Olney, 10 of the 27 fields were predicted as not having Karnal bunt but the regional level evaluation correctly predicted the whole region as conducive for Karnal bunt. This demonstrates that models developed using regional weather variables (especially rainfall) may not always produce correct predictions on local levels because of variation within the region.

Radar rainfall measurements have previously been used for site-specific modeling and the relationship between gauge-based and radar-based measurements has been thoroughly discussed $(18,49,50)$. The primary advantage of radar-based rainfall measurement over gauge-based measurement is its site specificity which enables it to account for local variability. Even though there is currently a good relationship between the two methods of rainfall measurement, it is still far from a perfect one-to-one relationship. Therefore, use of gauge-based rainfall data in the model would lead to erroneous conclusions. Arrangements can be made with the NWS for obtaining radar rainfall for desired locations. In Texas, radar-based rainfall data for any day of the year can be downloaded from the TWC by entering the latitude/longitude coordinates for any field location in Texas.

Karnal bunt has not been detected in Texas wheat fields since 2002. This can be largely attributed to the strict quarantine regulations, which included removal of the host crop from rotation 
schedules and the nonconduciveness of weather conditions during some of these years. This doesn't necessarily imply that there will not be Karnal bunt outbreaks in the future. The odds are that once established in the soil, $T$. indica may continue to cause problems unrelated to its significance as a pathogen. The model developed in this study is potentially useful if incorporated in spray-advisory programs in regulated areas where spraying for the disease could be cost effective. However, it has the limitations of predicting only favorable or unfavorable conditions and not the degree of disease severity related to the observed conditions. The model needs to be further evaluated and updated for an extended period in conjunction with fungicidal sprays.

\section{ACKNOWLEDGMENTS}

This research was conducted under a specific cooperative agreement between Texas A\&M University and the USDA-ARS under project number 5430-21000-005-00D. Mention of the trademark of a proprietary product does not constitute a guarantee or warranty of product by the United States Department of Agriculture, and does not imply its approval to the exclusion of other products that may also be suitable.

\section{LITERATURE CITED}

1. Afifi, A., Clark, V. A., and May, S. 2004. Computer-Aided Multivariate Analysis. 4th ed. Chapman and Hall/CRC, Boca Raton, FL.

2. Aujla, S. S., Sharma, Y. R., Chand, K., and Sawney, S. S. 1977. Influence of weather factors on the occurrence and epidemiology of Karnal bunt disease of wheat in the Punjab. Indian J. Ecol. 4:71-74.

3. Babadoost, M. 2000. Comments on the zero-tolerance quarantine of Karnal bunt of wheat. Plant Dis. 84:711-712.

4. Bains, S. S., and Dhaliwal, H. S. 1990. Production of Neovossia indica on host and non-host plants. Plant Soil 126:85-89.

5. Baker, R. H. A., Sanford, C. E., Jarvis, C. H., Cannon, R. J. C., MacLeod, A., and Walters, K. F. A. 2000. The role of climatic mapping in predicting the potential geographical distribution of non-indigenous pests under current and future climates. Agric. Ecosyst. Environ. 82:57-71.

6. Beattie, B. R. 1999. Karnal bunt: A wimp disease but irresistible political opportunity. Choices: The magazine of food, farm and resource issues. 14:4-8.

7. Bonde, M. R., Nester, S. E., Olsen, M. W., and Berner, D. K. 2004. Survival of teliospores of Tilletia indica in Arizona field soils. Plant Dis. 88:804-810.

8. Bonde, M. R., Peterson, G. L., Schaad, N. W., and Smilanick, J. L. 1997. Karnal bunt of wheat. Plant Dis. 81:1370-1377.

9. Bonde., M. R., Peterson, G. L., Fuentes-Davila, G., Aujla, S. S., Nanda, G. S., and Phillips, J. G. 1996. Comparison of the virulence of isolates of Tilletia indica, causal agent of Karnal bunt of wheat, from India, Pakistan, and Mexico. Plant Dis. 80:1071-1074.

10. Carris, L. M., Castlebury, L. A., and Goates, B. J. 2006. Nonsystemic bunt fungi-Tilletia indica and T. horrida: A review of history, systematics, and biology. Annu. Rev. Phytopathol. 44:113-133.

11. Chona, B. L., Munjal, R. L., and Adlakha, K. L. 1961. A method for screening wheat plants for resistance to Neovossia indica. Indian Phytopathol. 14:99-101.

12. Crous, R. W., Van Jaarsveld, A. B., Castlebury, L. A., Carris, L. M., Frederick, R. D., and Pretorius, Z. A. 2001. Karnal bunt of wheat newly reported from the African Continent. Plant Dis. 85:561.

13. Dhaliwal, H. S. 1989. Multiplication of secondary sporidia of Tilletia indica on soil and wheat leaves and spikes and occurrence of Karnal bunt. Can. J. Bot. 67:2387-2390.

14. Dhiman, J. S., Bedi, P. S., and Mavi, H. S. 1984. Relationship among temperature, humidity, and occurrence of Karnal bunt of wheat. Indian J. Ecol. 11:134-138.

15. Dowell, F. E., Boratynski, T. N., Ykema, R. E., Dowdy, A. K., and Staten, R. T. 2002. Use of optical sorting to detect wheat kernels infected with Tilletia indica. Plant Dis. 86:1011-1013.

16. Duran, R. 1972. Aspects of teliospore germination in North American smut fungi II. Can. J. Bot. 50:2569-2573.

17. Duran, R., and Cromarty, R. 1977. Tilletia indica: A heterothallic wheat bunt fungus with multiple alleles controlling incompatibility. Phytopathology 67:812-815.

18. Fulton, R. A., Breidenbach, J. P., Seo, D. J., Miller, D. A., and O'Bannon, T. 1998. The WSR-88D rainfall algorithm. Weather Forecast. 13:377-395.

19. Garrett, K. A., and Bowden, R. L. 2002. An Allee effect reduces the invasive potential of Tilletia indica. Phytopathology 92:1152-1159.

20. Goates, B. J., and Jackson, E. W. 2006. Susceptibility of wheat to Tilletia indica during stages of spike development. Phytopathology 96:962-966.
21. Holmes, G. J., Jackson, L. F., and Perring, T. M. 1997. Imperial Valley conditions limit Karnal bunt in wheat. Calif. Agric. 51:29-33.

22. Hosmer, D. W., and Lemeshow, S. 2000. Applied Logistic Regression. 2nd ed. John Wiley \& Sons, New York.

23. Jhorar, O. P., Mavi, H. S., Sharma, I., Mahi, G. S., Mathauda, S. S., and Singh, G. 1992. A biometeorological model for forecasting Karnal bunt disease of wheat. Plant Dis. Res. 7:204-209.

24. Jhorar, O. P., Sharma, I., Mavi, H. S., Aujla, S. S., and Nanda, G. S. 1993. Forecasting models for effective application of fungitoxicants in the management of Karnal bunt. Indian J. Mycol. Plant Pathol. 23:78-89.

25. Joshi, L. M., Singh, D. V., and Srivastava, K. D. 1983. Karnal bunt: A minor disease that is now a threat to wheat. Bot. Rev. 49:309-330.

26. Krishna, A., and Singh, R. A. 1983. Longevity of teliospores of Neovossia indica causing Karnal bunt of wheat. Indian J. Mycol. Plant Pathol. 13:97-98.

27. Mitra, M. 1931. A new bunt of wheat in India. Ann. Appl. Biol. 18:178179.

28. Murray, G. M., and Brennan, J. P. 1998. The risk to Australia from Tilletia indica, the cause of Karnal bunt of wheat. Aust. Plant Pathol. 27:212-225.

29. Nagarajan, S., Aujla, S. S., Nanda, G. S., Sharma, I., Goel, L. B., Kumar., J., and Singh, D. V. 1997. Karnal bunt (Tilletia indica) of wheat-A review. Rev. Plant Pathol. 76:1207-1214.

30. Royer, M. H., and Rytter, J, 1985. Artificial inoculation of wheat with Tilletia indica from Mexico and India. Plant Dis. 69:317-319.

31. Rush, C. M., Stein, J. M., Bowden, R. L., Riemenschneider, R., Boratynski, T. N., and Royer, M. H. 2005. Status of Karnal bunt of wheat in the United States 1996 to 2004. Plant Dis. 89:212-223.

32. Sharma, I., and Nanda, G. S. 2003. Effect of prolonged period of fog/rain from sowing of wheat to pre-boot stage on Karnal bunt development. Ann. Plant Prot. Sci. 11:93-95.

33. Sidhartha, V. S., Singh, D. V., Srivastava, K. D., and Aggarwal, R. 1995. Some epidemiological aspects of Karnal bunt of wheat. Indian Phytopathol. 48:419-426.

34. Singh, B. B., Aujla, S. S., and Sharma, I. 1993. Integrated pest management of wheat Karnal bunt. Int. J. Pest Manage. 39:431-434.

35. Singh, D., Singh, R., Rao, V. U. M., Karawasra, S. S., and Beniwal, M. S. 1996. Relation between weather parameters and Karnal bunt (Neovossia indica) in wheat (Triticum aestivum). Indian J. Agric. Sci. 66:522-525.

36. Singh, D. V., Srivastiva, K. D., Aggarwal, R., and Jain, S. K. 1996. Factors associated with development and spread of Karnal bunt of wheat (Triticum aestivum) in north-western India. Indian J. Agric. Sci. 66:374-383.

37. Singh, R. A., and Krishna, A. 1982. Susceptible stage for inoculation and effect of Karnal bunt on viability of wheat seed. Indian Phytopathol. 35:54-56.

38. Smilanick, J. L., Hoffmann, J. A., Cashion, N. L., and Prescott, J. M. 1987. Evaluation of seed and foliar fungicides for control of Karnal bunt of wheat. Plant Dis. 71:94-96.

39. Smiley, B. W. 1997. Risk assessment for Karnal bunt occurrence in the Pacific Northwest. Plant Dis. 81:689-692.

40. Stansbury, C. D., and McKirdy, S. J. 2002. Forecasting climate suitability for Karnal bunt of wheat: A comparison of two meteorological methods. Aust. Plant Pathol. 31:81-92.

41. Stansbury, C. D., and Pretorius, Z. A. 2001. Modeling the potential distribution of Tilletia indica in South Africa, the cause of Karnal bunt of wheat. S. Afr. J. Plant Soil. 18:159-168.

42. Stein, J. M., Maples, H. W., and Rush, C. M. 2005. Epidemiology of Tilletia indica teliospores in regulated wheat fields in Texas. Plant Dis. 89:828-833

43. Stevens, J. 1986. Applied Multivariate Statistics For The Social Sciences. Lawrence Erlbaum, Hillsdale, NJ.

44. Tabachnick, B. G., and Fidell, L. S. 2007. Using Multivariate Analysis. 5th ed. Pearson, New York.

45. Warham, E. J. 1986. Karnal bunt disease of wheat: A literature review. Trop. Pest Manage. 32:229-242.

46. Warham, E. J. 1990. A comparison of inoculation techniques for assessment of germplasm susceptibility to Karnal bunt (Tilletia indica) disease of wheat. Ann. Appl. Biol. 116:43-60.

47. Warham, E. J., Prescott, J. M., and Griffiths, E. 1989. Effectiveness of chemical seed treatment in controlling Karnal bunt of wheat. Plant Dis. 73:585-588

48. Webster, J. 1980. Introduction to Fungi. 2nd ed. Cambridge University Press, London.

49. Workneh, F., Narasimhan, B., Srinivasan, R., and Rush, C. M. 2004. Potential of radar-estimated rainfall for plant disease risk forecast. Phytopathology 94:25-27.

50. Workneh, F., Narasimhan, B., Srinivasan, R., and Rush, C. M. 2006. Assessment of regional site-specific sorghum ergot severity potential using radar-rainfall measurement. Plant Dis. 90:204-207.

51. Ykema, R. E., Floyd, J. P., Palm, M. E., and Peterson, G. L. 1996. First report of Karnal bunt in the United States. Plant Dis. 80:1207. 